\title{
Myf5 gene polymorphisms and production performance traits in Songliao white geese
}

\author{
J.B. Wu, L.P. Cao, M.M. Li, N.N. Du, H.L. Huang and Y. Jin \\ Agricultural College of Yanbian University, Yanji, China \\ Corresponding author: Y. Jin \\ E-mail: yijin@ybu.edu.cn
}

Genet. Mol. Res. 12 (4): 6052-6058 (2013)

Received April 25, 2013

Accepted September 15, 2013

Published December 2, 2013

DOI http://dx.doi.org/10.4238/2013.December.2.3

\begin{abstract}
To explore the relationship between Myf5 gene polymorphisms and production performance traits in Songliao white geese, we used the chicken Myf5 sequence to design primers and amplified part of the exon 1 sequence of the Songliao white goose Myf5 gene. Results of single-strand conformation polymorphism polymerase chain reaction analysis revealed polymorphisms of the amplified fragment, including three genotypes $(\mathrm{AA}, \mathrm{AB}$, and $\mathrm{BB})$. Three varieties were dominated by allele A and were mainly expressed in AA genotypes. We also identified that the Myf5 gene has one single nucleotide change $(A \rightarrow G)$ on exon 1 at locus 1344 , and another $(\mathrm{G} \rightarrow \mathrm{C})$ at locus 1410 . Analysis of variance showed significant differences between genotypes before slaughter in live weight, carcass weight, eviscerated weight, leg muscle weight, weight of the wings, and slaughter rate. There were no significant differences with respect to other growth and carcass traits evaluated.
\end{abstract}

Key words: Songliao white geese; $M y f 5$ gene; Slaughter performance; Exon 1 


\section{INTRODUCTION}

Myf5 is one of the members of the myogenic determining $(M y o D)$ factor gene family. Muscle growth requires myoblast proliferation and differentiation of $M y o D$ family regulation. Members of the $M y o D$ family encode 4 types of muscle-specific transcription factors, namely $M y o D, M y o G, M y f 5$, and $M y f 6$ (MRf4), which are key regulators of skeletal muscle generation (Naidu et al., 1995). In addition, MyoD family genes share the myogenic basic helix-loop-helix (bHLH) transcription factor domain, which can activate muscle-specific genes (Rudnicki et al., 1993; Kim et al., 1999). Although several studies have focused on $M y o D$ and $M y o G$ genes, the Myf5 gene, which is difficult to study, has received less attention, particularly in geese. Recently, however, the potential importance of $M y f 5$ has attracted the attention of researchers.

The Songliao white goose is a new line of goose meat that was developed using advanced molecular breeding methods of existing geese species. Songliao geese are characterized as fast growing, with high velvet meat production, good reproductive performance, high quality meat, and disease resistance (Piao et al., 2010). This study investigated polymorphisms in the goose Myf5 gene from Songliao white geese, in order to find unique SNP markers and their relationships to carcass traits. The data obtained will help lay the foundation for determining genetic markers for improving goose production traits.

\section{MATERIAL AND METHODS}

\section{Materials}

Thirty-eight unified, standard-bred Songliao white geese were slaughtered at 90 days of age. Liver tissues were obtained and immediately frozen in liquid nitrogen until used to extract genomic DNA by the phenol-chloroform method.

\section{Reagents}

The DNA gel extraction kit was purchased from AXYGEN, the pMD18-T vector kit was purchased from Takara, the Taq enzyme and dNTP were purchased from TIANGEN, and competent DH5 $\alpha$ cells were obtained from our laboratory's stock population.

\section{Primer design and single-strand conformation polymorphism-polymerase chain reaction (SSCP-PCR) detection}

Primers were designed by reference to chicken (GenBank: X73250) sequences. The primer sequences for the exon 1 sequences (upstream primer: 5'-CCAGTTCTCCCCATCC GA-3'; downstream primer: 5'-GGCAGGTGATAGTAGTTCTCC-3') were synthetized by Beijing Luhe Genomics Technology Co., Ltd. The PCR system was run in a $25-\mu \mathrm{L}$ total volume, including $2.5 \mu \mathrm{L} 10 \mathrm{X}$ buffer, $1 \mu \mathrm{L} 2.5 \mathrm{mM}$ dNTP, $0.5 \mu \mathrm{L}$ of each $10 \mu \mathrm{M}$ upstream and downstream primer, $1.0 \mathrm{U} 100 \mathrm{ng} / \mu \mathrm{L} \mathrm{Taq}, 1 \mu \mathrm{L}$ DNA template, and double-distilled water. PCR conditions were as follows: denaturation at $95^{\circ} \mathrm{C}$ for $5 \mathrm{~min}$, denaturation at $94^{\circ} \mathrm{C}$ for 30 $\mathrm{s}, 56^{\circ} \mathrm{C}$ annealing for $30 \mathrm{~s}$, extension at $72^{\circ} \mathrm{C}$ for $30 \mathrm{~s}$, for $30 \mathrm{cycles}$, and a final extension at $72^{\circ} \mathrm{C}$ for $5 \mathrm{~min}$. The amplification products were detected by electrophoresis on $1 \%$ agarose 
gel. PCR amplification products were denatured at $98^{\circ} \mathrm{C}$ for $10 \mathrm{~min}$, pre-cooled on ice for 10 min, and subjected to $8 \%$ denatured polyacrylamide gel electrophoresis at $180 \mathrm{~V}$ for $14-16 \mathrm{~h}$, silver stained, and typed.

\section{Sequencing}

Different homozygous genotypes were selected using the DNA gel extraction kit recycling purpose bands, cloned into the pMD18-T vector, transformed into DH5 $\alpha$ competent cells, and cultured overnight at $37^{\circ} \mathrm{C}$. The positive bacterial cells identified by PCR were sent to Beijing Luhe Genomics Technology Corporation for sequencing.

\section{Statistical analysis}

Genotype and gene frequencies were calculated and checked for deviations from HardyWeinberg equilibrium. A fixed model was employed to investigate the effects of different genotypes. The SPSS 12.0 statistical software was used for variance analysis of production traits, and single factor and multiple comparisons were used to measure the effects of different marker genotypes on production traits (means \pm standard deviation). The linear model used was as follows:

$$
Y_{i j}=\mu+\text { marker }_{j}+e_{\mathrm{ij}}
$$

where $Y_{i j}$ represents individual phenotypic values, $\mu$ is the population mean, marker $_{j}$ is the marker genotype effect, and $e_{i j}$ is the random error.

\section{Slaughter performance measurement indicators}

In this study, ante-mortem live weight, carcass weight, semi-eviscerated weight, eviscerated weight, breast muscle weight, leg muscle weight, abdominal fat weight, wing weight, head weight, and claw poultry slaughter weight were all determined and used to calculate the slaughtering rate. Slaughter performance indicators were measured in accordance with poultry production performance and calculation guidelines published in 1984 by the National Association of Poultry Breeding.

\section{RESULTS}

\section{Myf5 gene PCR amplification}

The PCR results are shown in Figure 1. The length of the amplification product was $432 \mathrm{bp}$, and non-specific bands were not observed, indicating that the amplification product could be used for SSCP analysis.

\section{SSCP analysis} (Figure 2).

After SSCP analysis, there were 3 genotypes detected, defined as AA, AB, and $\mathrm{BB}$ 


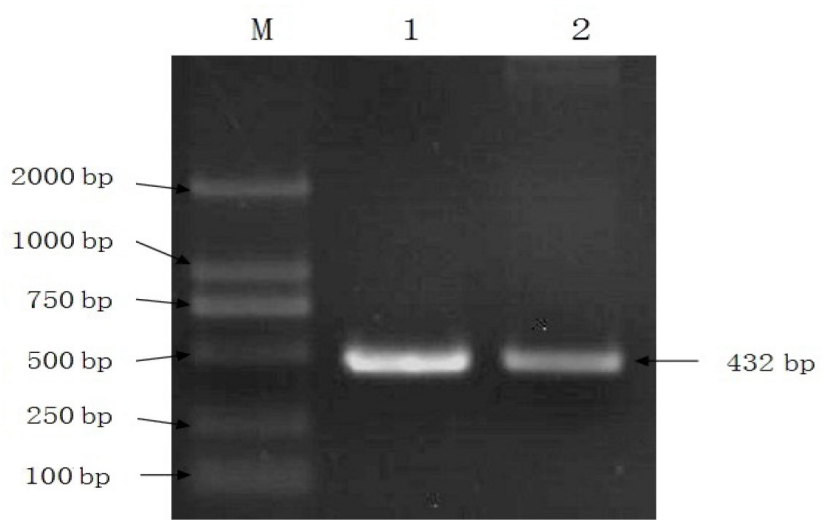

Figure 1. Electrophoresis map of the goose Myf5 gene PCR amplification. Lanes 1 and $2=$ amplified fragments; lane $M=\mathrm{D} 2000$.

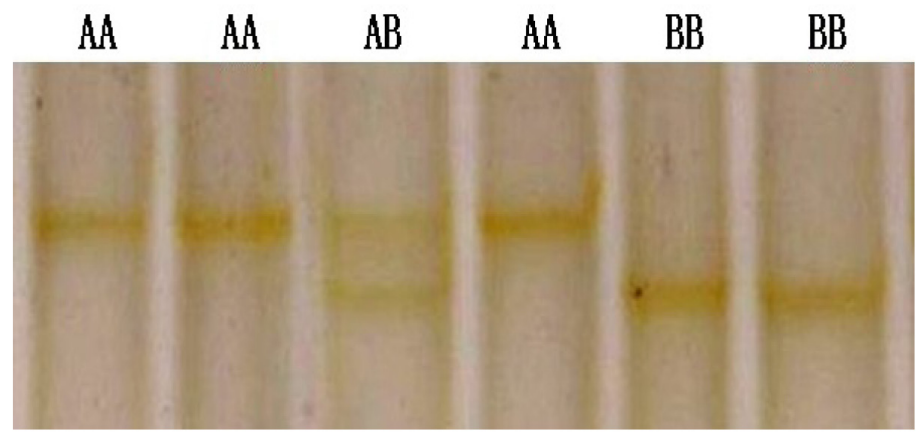

Figure 2. Myf5 gene SSCP analysis of amplified products.

\section{Sequence analysis results}

The genotypes $\mathrm{AA}$ and $\mathrm{BB}$ were sequenced and matched with the original sequence, revealing one single base change $(A \rightarrow G)$ at position 1344 , and another $(G \rightarrow C)$ at position 1410 of exon 1 (Figure 3).
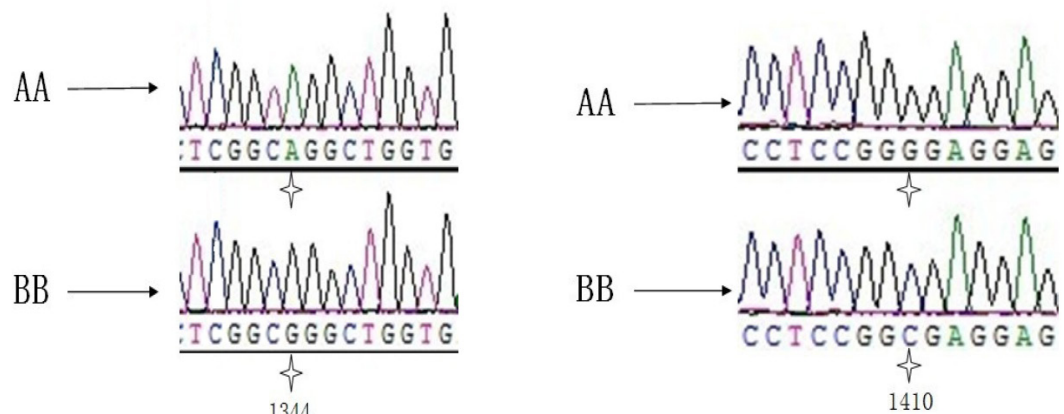

Figure 3. Myf5 gene sequencing peak comparison charts of different genotypes. 


\section{Genotype frequencies}

Genotype frequencies were calculated based on the genotyping results, and tested for Hardy-Weinberg equilibrium. Results revealed that the AA genotype was dominant, and that A was the predominant allele (Table 1).

\begin{tabular}{|c|c|c|c|c|c|c|}
\hline \multicolumn{3}{|c|}{ Genotype frequency } & \multicolumn{2}{|c|}{ Allele frequency } & \multirow[t]{2}{*}{$\chi^{2}$} & \multirow[t]{2}{*}{$\mathrm{P}$} \\
\hline AA & BB & $\mathrm{AB}$ & A & B & & \\
\hline $0.789(\mathrm{~N}=30)$ & $0.132(\mathrm{~N}=5)$ & $0.079(\mathrm{~N}=3)$ & 0.829 & 0.171 & 19.787 & $<0.01$ \\
\hline
\end{tabular}

$\chi^{2}$ distribution of different genotypes for the Hardy-Weinberg equilibrium test values.

\section{Relationships among different genotypes and carcass traits}

As shown in Table 2, the AA genotype had a significantly stronger effect on live weight, carcass weight, semi-eviscerated weight, eviscerated weight, and wing weight before slaughter, compared to the $\mathrm{BB}$ genotype $(\mathrm{P}<0.05)$. Inter-individual differences were not significant with respect to the 3 genotypes. Specifically, genotype AA had positive effects on ante-mortem live weight, carcass weight, semi-eviscerated weight, eviscerated weight, and wing weight. Individuals with the BB genotype had significantly lower leg muscle weights compared to individuals of genotype $\mathrm{AA}$ or $\mathrm{AB}(\mathrm{P}<0.05)$, suggesting a negative impact of genotype $\mathrm{BB}$ on leg muscle weight. Individuals of genotype $\mathrm{AB}$ had significantly higher semi-eviscerated and eviscerated yield traits compared to individuals of genotype $\mathrm{AA}$ ( $\mathrm{P}<0.05$ and $\mathrm{P}<0.01$, respectively), suggesting that genotype $\mathrm{AB}$ has a positive impact on these traits. No significant differences were detected for breast muscle weight, abdominal fat weight, head weight, claw weight, slaughter rate, breast muscle rate, leg muscle rate, or abdominal fat percentage.

\begin{tabular}{|c|c|c|c|}
\hline Traits & AA type $(\mathrm{N}=30)$ & AB type $(\mathrm{N}=3)$ & BB type $(\mathrm{N}=5)$ \\
\hline Before slaughter live weight (g) & $4506.67 \pm 65.08^{\mathrm{a}}$ & $4273.33 \pm 205.78$ & $4076.00 \pm 159.40^{b}$ \\
\hline Carcass weight $(\mathrm{g})$ & $3749.37 \pm 54.98^{\mathrm{a}}$ & $3597.67 \pm 173.86$ & $3406.00 \pm 134.67^{b}$ \\
\hline Semi-eviscerated weight $(\mathrm{g})$ & $3404.20 \pm 49.29^{\mathrm{a}}$ & $3318.33 \pm 155.88$ & $3087.40 \pm 120.75^{b}$ \\
\hline Eviscerated weight (g) & $2991.70 \pm 43.17^{\mathrm{a}}$ & $2965.00 \pm 136.52$ & $2743.40 \pm 105.74^{b}$ \\
\hline Breast muscle weight ( $\mathrm{g}$ ) & $496.40 \pm 7.94$ & $494.00 \pm 25.09$ & $457.80 \pm 19.44$ \\
\hline Leg muscle weight $(\mathrm{g})$ & $501.70 \pm 6.93^{\mathrm{a}}$ & $503.33 \pm 21.91^{\mathrm{a}}$ & $462.00 \pm 16.97^{\mathrm{b}}$ \\
\hline Abdominal fat weight ( $\mathrm{g}$ ) & $50.93 \pm 3.14$ & $46.00 \pm 9.93$ & $46.40 \pm 7.69$ \\
\hline Wings weight $(\mathrm{g})$ & $445.33 \pm 8.87^{\mathrm{a}}$ & $421.00 \pm 28.04$ & $397.00 \pm 21.72^{b}$ \\
\hline Head weight $(\mathrm{g})$ & $159.67 \pm 2.90$ & $155.33 \pm 9.18$ & $144.40 \pm 7.11$ \\
\hline Pawl weight (g) & $129.46 \pm 2.84$ & $117.67 \pm 8.98$ & $116.00 \pm 6.95$ \\
\hline Slaughter rate (\%) & $83.20 \pm 0.24$ & $84.17 \pm 0.76$ & $83.52 \pm 0.59$ \\
\hline Semi-eviscerated rate (\%) & $75.54 \pm 0.30^{\mathrm{b}}$ & $77.73 \pm 0.96^{\mathrm{a}}$ & $75.73 \pm 0.74$ \\
\hline Eviscerated rate (\%) & $66.41 \pm 0.33^{\mathrm{B}}$ & $69.44 \pm 1.03^{\mathrm{A}}$ & $67.25 \pm 0.80$ \\
\hline Breast muscle rate (\%) & $16.66 \pm 0.23$ & $16.66 \pm 0.72$ & $16.65 \pm 0.55$ \\
\hline Leg muscle rate (\%) & $16.81 \pm 0.18$ & $16.97 \pm 0.57$ & $16.80 \pm 0.44$ \\
\hline Abdominal fat percentage (\%) & $1.68 \pm 0.11$ & $1.55 \pm 0.36$ & $1.66 \pm 0.28$ \\
\hline
\end{tabular}

$\mathrm{P}<0.05$ for significant differences between lowercase letters. $\mathrm{P}<0.01$ for highly significant differences between uppercase letters. 


\section{DISCUSSION}

Myf5 plays a very important role in the growth process of muscles, regulating the number and size of muscle fibers. Therefore, studies of the Myf5 gene will be of high significance for livestock poultry production, meat quality, and flavor improvement.

Kiefer and Hauschka (2001) demonstrated dynamic changes in Myf5 expression in the chick embryo. Myf5 expression first appeared in the stage 3 primitive streak of chicken embryo muscle development, and showed transient lower levels of expression in non-muscle mesoderm. Thereafter, Myf5 was concurrently expressed with the occurrence of the sarcomere germ layers in the pre-sub section (pre-segmented mesoderm), and showed dynamic regional expression changes in the I-IV somite (Ernst et al., 1994; Black et al., 1995; Goureau et al., 2001). Up- and downregulation experiments have revealed that $M y f 5$ plays a critical role in the myogenic process of vertebrates, especially in the muscle differentiation stage (Tatusova and Madden, 1999). Cooper et al. (1999) suggested that a negative feedback regulation ring might exist between $M y o D$ and $M y f 5$. Indeed, Myf5 has been shown to promote $M y o D$ expression, while MyoD inhibits Myf5 expression (Twardizik et al., 1990).

In a gene level study, Cieslak et al. (2002) showed that the regulatory mechanism of Myf5 in mammals was complex. Maak et al. (2006) conducted an in-depth comparative study of Myf5, demonstrating that various regulatory factors within the region of the gene in mice, rabbits, pigs, cattle, dogs, and chickens ( $\mathrm{H} 1$ and 2; $\mathrm{M} 6 \mathrm{EH})$ were all highly conserved. The function of these regulatory factors has been determined in transgenic mice, which are all temporally and spatially expressed independently in different regions during mouse embryo development (Williams et al., 1990; Welsh et al., 1991; Yablonka-Reuveni et al., 1999).

In this study, the PCR-SSCP technique was used to detect Songliao white goose Myf5 gene polymorphisms. The analysis revealed 3 genotypes, in which the AA genotype was dominant, and the A allele showed a dominant advantage. The frequency of the $\mathrm{A}$ and $\mathrm{B}$ alleles were 0.829 and 0.171 , respectively. $\mathrm{AA}, \mathrm{AB}$, and $\mathrm{BB}$ genotype frequencies were $0.789,0.079$, and 0.132 , respectively. The $\chi^{2}$ test showed that the locus is in Hardy-Weinberg disequilibrium (P $<0.01$ ), which may be related to the high homozygosity of the population and the selection of certain traits, indicating that this group can be further adjusted.

Results of this study revealed that different genotypes had significantly different effects on pre-slaughter live weight, carcass weight, semi-eviscerated weight, eviscerated weight, leg muscle weight, wing weight, and dressing percentage traits, whereas most other growth and carcass traits showed no significant differences among genotypes. The AA genotype showed relatively high trait association values, indicating that this genotype could be used as a molecular marker for screening high value slaughter traits that could be used to improve growth of Songliao white geese. Therefore, more in-depth studies of relationships between goose growth traits and $M y f 5$ are needed to confirm its suitability as a candidate gene.

\section{ACKNOWLEDGMENTS}

Research supported by the Department of Finance Projects of Jilin Province (\#2010).

\section{REFERENCES}

Black BL, Martin JF and Olson EN (1995). The mouse MRF4 promoter is trans-activated directly and indirectly by muscle-specific transcription factors. J. Biol. Chem. 270: 2889-2892. 
Cieslak D, Kuryl J, Kapelanski W, Pierzchala M, et al. (2002). Relationship between genotypes at MYOG, MYF3 and MYF5 loci and carcass meat and fat deposition traits in pigs. Anim. Sci. Papers Rep. 20: 77-92.

Cooper RN, Tajbakhsh S, Mouly V, Cossu G, et al. (1999). In vivo satellite cell activation via Myf5 and MyoD in regenerating mouse skeletal muscle. J. Cell Sci. 112: 2895-2901.

Ernst CW, Vaske DA, Larson RG, White ME, et al. (1994). Rapid communication: MspI restriction fragment length polymorphism at the swine MYF6 locus. J. Anim. Sci. 72: 799.

Goureau A, Garrigues A, Tosser-Klopp G, Lahbib-Mansais Y, et al. (2001). Conserved synteny and gene order difference between human chromosome 12 and pig chromosome 5. Cytogenet. Cell Genet. 94: 49-54.

Kiefer JC and Hauschka SD (2001). Myf-5 is transiently expressed in nonmuscle mesoderm and exhibits dynamic regional changes within the presegmented mesoderm and somites I-IV. Dev. Biol. 232: 77-90.

Kim HS, Park EW, Yoon DH, Kim HB, et al. (1999). Partial sequence of the bovine (Bos taurus coreanae) myogenic factor encoding gene MyoD. Asian-Aust. J. Anim. Sci. 12: 689-694.

Maak S, Neumann K and Swalve HH (2006). Identification and analysis of putative regulatory sequences for the MYF5/ MYF6 locus in different vertebrate species. Gene 379: 141-147.

Naidu PS, Ludolph DC, To RQ, Hinterberger TJ, et al. (1995). Myogenin and MEF2 function synergistically to activate the MRF4 promoter during myogenesis. Mol. Cell Biol. 15: 2707-2718.

Piao HX, Jin Y and Cao Y (2010). Research of GH gene polymorphism and production performance in Songliao White Geese. Jiangxi Nong Ye Da Xue Xue Bao 32: 1240-1244.

Rudnicki MA, Schnegelsberg PN, Stead RH, Braun T, et al. (1993). MyoD or Myf-5 is required for the formation of skeletal muscle. Cell 75: 1351-1359.

Tatusova TA and Madden TL (1999). BLAST 2 Sequences, a new tool for comparing protein and nucleotide sequences. FEMS Microbiol. Lett. 174: 247-250.

Twardizik DR, Mikovits JA, Ranchalis JE, Purchio AF, et al. (1990). $\gamma$-interferon-induced activation of latent transforming growth factor- $\beta$ by human monocytes. Ann. New York Acad. Sci. 593: 276-284.

Welsh J, Petersen C and McClelland M (1991). Polymorphisms generated by arbitrarily primed PCR in the mouse: application to strain identification and genetic mapping. Nucleic Acids Res. 19: 303-306.

Williams JG, Kubelik AR, Livak KJ, Rafalski JA, et al. (1990). DNA polymorphisms amplified by arbitrary primers are useful as genetic markers. Nucleic Acids Res. 18: 6531-6535.

Yablonka-Reuveni Z, Rudnicki MA, Rivera AJ, Primig M, et al. (1999). The transition from proliferation to differentiation is delayed in satellite cells from mice lacking MyoD. Dev. Biol. 210: 440-455. 